International Journal of Engineering \& Technology, $7(3.6)(2018) 21-23$
International Journal of Engineering \& Technology
SPC
Website: www.sciencepubco.com/index.php/IJET
Research paper Research paper, Short communication, Review, Technical paper

\title{
A Study on Motivations for Career Switching to Entrepreneurship in Handicrafts Among Women
}

\author{
G. Deya Gayatri ${ }^{*}$, C.S. Udhayakumar ${ }^{2}$ \\ ${ }^{1}$ Amrita School Of Business, Amrita Vishwa Vidyapeetham, Coimbatore, India. \\ ${ }^{2}$ Amrita School Of Business, Amrita Vishwa Vidyapeetham, Coimbatore, India. \\ E-Mail:Udhayji@Gmail.Com \\ *Corresponding Author E-Mail:Deyagayatrig@Gmail.Com
}

\begin{abstract}
The handicraft sector in India, due to its rich history and promising growth has been attracting a large number of entrepreneurs in recent times. A significant portion of these are women who have quit their previous careers due to the allure of the handicrafts sector. This study makes a modest attempt to explore the reasons why women choose to switch their careers at various organizations in favor of becoming a handicraft entrepreneur. The methodology employed uses a structured questionnaire which was circulated among women entrepreneurs through mail survey. The data was collected from select 53 women entrepreneurs in India who managed small to medium sized enterprises and who met the criteria of having quit their previous jobs to pursue their current chosen career and it was analyzed through the statistical software S.P.S.S. The results reveal that most of the respondents were motivated to engage in an entrepreneurial career in handicrafts because it made sense, they regarded it as a personal achievement and for some of them it was because they wanted to challenge themselves.
\end{abstract}

Keywords: Career switching, entrepreneurship, handicrafts, women.

\section{Introduction}

"Handicrafts are the ones produced by artisans, either completely handmade or with the help of manual or mechanical tools, as long as the direct manual contribution of the artisan remains the most substantial component of the finished product. Handicrafts are made without restriction in terms of quantity and using raw materials from sustainable resources. The special nature of artisanal products derives from their distinctive features, which can be utilitarian, aesthetic, artistic, creative, culturally significant, decorative, functional, traditional, religiously and socially symbolic and significant."

There are many definitions for handicrafts, but this one adopted by the United Nations Educational, Scientific and Cultural Organization (UNESCO) is one which best captures the essence of the word. It is the human input which forms the most significant part of a handcrafted item and which in turn makes each one unique from the rest [1].

Indian handicrafts are world renowned because of their variety, skill involved and rich finish. The handicraft industry in India is labor intensive and largely unorganized. But this does not dent the popularity of the handicrafts sector in India as it has shown continuous growth over the years. It is the one sector besides agriculture which provides employment to a large section of the rural society besides earning revenue. The Export Promotion Council for Handicrafts (EPCH) has reported that the exports of handicrafts in the year 2016-17 were 3.66 billion dollars. There has been a renewed interest in Indian handicrafts of late thanks to the efforts of a growing body of entrepreneurs engaged in producing and selling handicrafts. A significant section of these entrepreneurs are women and some of them are ones who quit their former jobs unable to resist the allure of the world of handicrafts. This study attempts to understand the motivations for women to quit their former careers in order to take up entrepreneurship specifically in the handicraft sector

\section{Literature review}

\section{Handicrafts in India}

In a country with a rich and diverse cultural heritage such as India, it is unsurprising to see a vast variety of handicrafts that any person can conceive. The handicraft industry in India mostly has its roots in rural areas and small towns. The individuals engaged in the production of handicrafts in India are mostly from rural background and comprise mostly of women and economically disadvantaged communities [2].

However its contribution to the national revenue has risen over the years from a meager Rs. 11 crores in 1960-61 to a mammoth Rs. 8718.94 crores in a matter of four decades. However there is a huge untapped potential as India's handicrafts only contribute up to $1.5 \%$ of India's total exports and only $1.2 \%$ of the global share of handicrafts market. This is despite the fact that the industry has advantages such as low capital requirements, high potential for export and high ratio of value addition [3]. However this gap is on the declining path as many women show keen interest in taking up handicrafts and handlooms as entrepreneurs across urban, semiurban and even rural areas. While the women from rural areas have engaged in handicraft production since time immemorial, with some estimating up to $47.42 \%$ of the participating force being women, of which at least $37.11 \%$ belong to the backward communities such as Scheduled castes/Scheduled Tribes and other 
minority communities[4].

This study however focuses on women who have chosen entrepreneurship in handicrafts after having previously worked in an unrelated career.

\section{Motivations for entrepreneurship among women}

The number of women engaging in entrepreneurship has seen a rise in past few decades, especially so in the developing countries. This comes as no surprise since developing countries have higher birth rates [5]; however the laws on maternity support and child care are lax which enables employers to exploit working women thereby preventing them from being able to perform to their fullest potential on both the workplace and household fronts [6]. These circumstances force women to create opportunities for themselves which align with their domestic responsibilities [7].

This seems to be the traditional explanation as to why women would seek entrepreneurship despite having a stable job in a large organization. With changing times however women seem to leave organizations for entirely different reasons. Besides the need for work-life balance other factors such as desire for challenge, selfdetermination as well as blocks to career advancement in the organization in which they work also were huge drivers of female entrepreneurship. It is important to note that women who left organizations due to these factors also measured success differently, for them success in terms of the traditional measures such as profit and business growth were less substantial in comparison to self-fulfilment and goal achievement. Also getting recognition for achieving something also seemed to be a prime motivator for women to choose entrepreneurship [8] [9].

Women entrepreneurs can also be classified as freedom seekers, security seekers and satisfaction seekers on the basis of motivation according to Helms (1997). Freedom seekers are women who were motivated to pursue entrepreneurship due to dissatisfaction or frustration in their previous career. Security seekers are women who seek to maintain and improve their social and economic status through entrepreneurship in the face of some personal tragedy such as loss of primary breadwinner or an accident which incapacitates them from performing their duties in their previous job. The satisfaction seekers were women with no prior work experience and took up entrepreneurship as a means to prove their self-worth [10].

The need to study participation of women in the labour force across different has never been more important than now. The GEM report of 2016-17 states that those economies which have a higher participation of females in their labour force have more resilience and as a consequence experience lesser number of economic growth slowdowns [11].

\section{Research Methodology}

\section{Data description and questionnaire development}

For this study, 53 female entrepreneurs who engaged in production of handicrafts were contacted. Care was taken to ensure that the respondents had taken up entrepreneurship in handicraft only after having previous work experience in an unrelated sector. The entrepreneurs were spread across India and were contacted through mail to participate in the survey and the sampling used was snowball sampling.

Of the respondents $32 \%$ were in the age group of 31-40 years. $30 \%$ of the respondents are unmarried and $15 \%$ are widowed. Education seems to be a priority among the respondents as majority of the respondents are either graduates $(28 \%)$ or post graduates $(23 \%)$.

The questionnaire was prepared and sent to the respondents through online mail survey. The 5 point Likert scale on reasons for motivation was adopted from Dubini (1988) and Turan and Kara (2007) [12] [13].

\section{Results}

The collected data was analyzed using T-test, Standard Deviation, Mean and Standard Error through SPSS software package. The confidence level under consideration for this study is $95 \%$.

Table I: Statistical Analysis of Motivations for Entrepreneurship

\begin{tabular}{|l|l|l|l|l|}
\hline $\begin{array}{l}\text { Motivations for } \\
\text { Entrepreneurship }\end{array}$ & Mean & $\begin{array}{l}\text { Standard } \\
\text { Deviation }\end{array}$ & $\begin{array}{l}\text { Standard } \\
\text { Error }\end{array}$ & t-test \\
\hline $\begin{array}{l}\text { Wanted greater freedom } \\
\text { to adopt my own } \\
\text { approach to work }\end{array}$ & 2.7547 & 1.61609 & 0.22199 & 12.4093 \\
\hline $\begin{array}{l}\text { Always wanted to be my } \\
\text { own boss }\end{array}$ & 3.1321 & 1.71013 & 0.23490 & 13.3334 \\
\hline $\begin{array}{l}\text { Wanted to make an idea } \\
\text { or innovation happen }\end{array}$ & 2.7358 & 1.54610 & 0.21237 & 12.8823 \\
\hline $\begin{array}{l}\text { Wanted to make more } \\
\text { money than was earning } \\
\text { before }\end{array}$ & 2.4528 & 1.53881 & 0.21137 & 11.6044 \\
\hline $\begin{array}{l}\text { Wanted to make a lot of } \\
\text { money or have a very } \\
\text { high income }\end{array}$ & 2.6604 & 1.67497 & 0.23007 & 11.5631 \\
\hline $\begin{array}{l}\text { Had been made } \\
\text { redundant }\end{array}$ & 1.8491 & 1.37835 & 0.18933 & 9.7663 \\
\hline $\begin{array}{l}\text { Wanted to develop a } \\
\text { hobby or some other } \\
\text { activity into a } \\
\text { commercial enterprise }\end{array}$ & 3.3019 & 1.48822 & 0.20442 & 16.1522 \\
\hline $\begin{array}{l}\text { Wanted to challenge } \\
\text { myself }\end{array}$ & 4.1132 & 1.13782 & 0.15629 & 26.3176 \\
\hline $\begin{array}{l}\text { Was dissatisfied in my } \\
\text { previous job }\end{array}$ & 3.7547 & 1.46636 & 0.20142 & 18.6412 \\
\hline $\begin{array}{l}\text { Wanted to achieve a } \\
\text { better position for myself } \\
\text { in society }\end{array}$ & 3.1132 & 1.53998 & 0.21153 & 14.7173 \\
\hline $\begin{array}{l}\text { Wanted to follow the } \\
\text { example of someone I } \\
\text { admired }\end{array}$ & 2.9434 & 1.51169 & 0.20765 & 14.1751 \\
\hline $\begin{array}{l}\text { Thought I would get } \\
\text { more respect working for } \\
\text { myself }\end{array}$ & 2.9623 & 1.49309 & 0.20509 & 14.4436 \\
\hline $\begin{array}{l}\text { Wanted to continue a } \\
\text { family tradition }\end{array}$ & 2.0566 & 1.41985 & 0.19503 & 10.5450 \\
\hline $\begin{array}{l}\text { Wanted to lead and } \\
\text { motivate others }\end{array}$ & 3.1321 & 1.65294 & 0.22705 & 13.7947 \\
\hline $\begin{array}{l}\text { To grow steadily and } \\
\text { employ others }\end{array}$ & 3.2453 & 1.49236 & 0.20499 & 15.8313 \\
\hline Welfare area of origin & 2.0755 & 1.50447 & 0.20665 & 10.0432 \\
\hline It made sense & 4.1132 & 0.93357 & 0.12824 & 32.0754 \\
\hline Better use of my skills & 3.3774 & 1.37598 & 0.18901 & 17.8691 \\
\hline Balancing family & 2.9434 & 1.58618 & 0.21788 & 13.5093 \\
\hline Personal accomplishment & 4.0755 & 1.07147 & 0.14718 & 27.6909 \\
\hline Onlfare of community thing I could do & 2.3019 & 1.57608 & 0.21649 & 10.6327 \\
\hline Thesults bas & 2.8679 & 1.59371 & 0.21891 & 13.1008 \\
\hline
\end{tabular}

The results based on the higher value of t-test are mentioned below:

A t-test value of 32.0754 indicates that the respondents felt that it made sense to start an entrepreneurial career in handicrafts.

A t-test value of 27.6909 indicates that the respondents started their entrepreneurial career in handicrafts as they regarded it as a personal achievement

A t-test value of 26.3176 indicates that the respondents started their entrepreneurial journey in the world of handicrafts because they wanted to challenge themselves.

Other significant reasons for choosing an entrepreneurial career over a previous job include dissatisfaction with previous job with a t-test score of 18.6412, better use of skills which the respondents possessed with a t-test score of 17.8691 and even the urge to develop a hobby or some other activity into a commercial enterprise with a t-test score of 16.1522 .

The results reveal that majority of the women chose a career in entrepreneurship with specific reference to the handicrafts sector out of their own volition and not because they were forced into it due to circumstances or otherwise.

\section{Limitations and Future Research}

The results reveal that majority of the women chose a career in entrepreneurship with specific reference to the handicrafts sector 
out of their own volition and not because they were forced into it due to circumstances or otherwise.

\section{Conclusion}

This study attempts to shed light on the motivations for women to take up handicraft entrepreneurship despite having a job in hand. The results reveal that women are increasingly taking up entrepreneurship in handicrafts as a result of their own will rather than being pushed into it. The traditional view has been that women step out to make it on their own when they are left with no choice. The results of this study disprove this notion. Moreover the need to understand female behavioural traits and personality traits has never been more pronounced than in the present as most studies have indicated that female participation in the labour force is a powerful weapon against poverty. Also in a developing country such as India which is prone to the vagaries of business and trade cycles it makes sense for a members of a household to work in different sectors or occupations so that when an adverse macroeconomic event occurs, the ill effects are lessened.

\section{References}

[1] Young GO, Synthetic structure of industrial plastics (Book style with paper title and editor), Plastics, 2nd ed. vol. 3, J. Peters, Ed. New York: McGraw-Hill, (1964), pp. 15-64.

[2] Ghouse SM, "Indian Handicraft Industry: Problems and Strategies", International Journal Of Management Research and Review, Vol.02, No.07,(2012), pp.1183-1199.

[3] Jadhav S, "Indian Handicrafts: Growing or Depleting?", IOSR Journal of Business and Management, (2013), pp.07-13.

[4] Ud Din TM, "Handicraft Production and Employment in Indian: an Economic Analysis", Global Journal Of Human Social Science: E Economics, (2014), pp.27-32.

[5] Vats N, "Indian Handicrafts and Globalization: A Review. IOSR Journal of Humanities and Social Science, (2014), pp.40-43.

[6] Manolova TS, Brush CG \& Edelman LF, "What do women entrepreneurs want? Strategic Change, (2008), pp.69-82.

[7] Roomi MA \& Parrott G, "Barriers to Development and Progression of Women Entrepreneurs in Pakistan", The Journal of Entrepreneurship, (2008), 59-72.

[8] Acs ZJ, Arenius P, Hay M \& Minniti M, "Global Entrepreneurship Monitor Executive Report”, Global Entrepreneurship Research Association, (2004).

[9] Buttner EH \& Moore DP, “Women's organizational exodus to entrepreneurship: Self-reported motivations and correlates with success", Journal of Small Business Management, (1997), pp.3446.

[10] Shane S, Kolvereid L \& Westhead P, "An exploratory examination of the reasons leading to new firm formation across country and gender", Journal of Business Venturing, (1991), pp.431-446.

[11] Helms MM, "Women and entrepreneurship: The appealing alternative", Business perspectives, (1997), pp.16-20.

[12] "Global Entepreneurship Monitor", Global Entrepreneurship Research Association (GERA), (2017).

[13] Dubini P, "The influence of motivations and environment on business start-ups: Some hints for public policies", Journal of Business Venturing, (1989), pp.11-26.

[14] Turan M \& Kara A, "An exploratory study of characteristics and attributes of Turkish entrepreneurs: A cross-country comparison to Irish entrepreneurs", Journal of International Entrepreneurship, (2007), pp.25-46. 